\title{
Coincident intra-abdominal presentation of lymphoma and tuberculosis after long-term iatrogenic immunosuppression
}

\author{
Balwant S Negi, ${ }^{1}$ Priyanka Thakur, ${ }^{2}$ Muninder K Negi, ${ }^{3}$ Swaroop Revannasiddaiah² \\ ${ }^{1}$ Surgery Department, Indira Gandhi Medical College, Shimla, India; \\ ${ }^{2}$ Radiation Therapy and Oncology Department, Regional Cancer Centre, Shimla, India; \\ ${ }^{3}$ Radiotherapy Department, Dr Rajendra Prasad Government Medical College, Tanda, Himachal Pradesh, India
}

Correspondence to Dr Swaroop Revannasiddaiah, swarooptheone@gmail.com

\section{DESCRIPTION}

A gentleman aged 49 years with a prior history of longterm immunosuppressive therapy (for moderate to severe Crohn's disease) presented to the emergency department with features of acute intestinal obstruction. In the preceding two decades, he had received various regimens containing a variety of immunosuppressive agents including prednisolone, cyclosporine and infliximab. On surgical exploration, there was free fluid in the abdomen, along with multiple nodular deposits over the gut loops and the mesentery (figure 1). One segment of the gut had an obstruction due to adhesions and resection-anastomosis was performed. The peritoneal fluid had an elevated adenosine deaminase level of 63 IU/1 (normal value $<39$ IU/l). ${ }^{1}$ The presence of Mycobacterium tuberculosis was confirmed by a PCR assay (Mycosure PCR- a test specific for
$M$ tuberculosis species). Pathological assessment however revealed non-Hodgkins lymphoma (NHL) which on characterisation was a B cell lymphoblastic lymphoma. Though the patient tolerated the surgery, the patient's poor general condition (Karnofsky's Performance Status score of 30\%) precluded the use of any chemotherapy. He was transitioned to supportive care in a hospice. The patient was diagnosed to have two concurrent diseases- tuberculosis (TB) co-existing with NHL. Both of TB and NHL can be attributed to long-term immunosuppression 23 which was employed as part of management of Crohn's disease. Immunosuppression (an integral part of current management in various clinical situations such as in auto-immune disorders and post-transplant patients) predisposes to infections and malignancies, and hence, an active vigilance against these must never be omitted in practise.

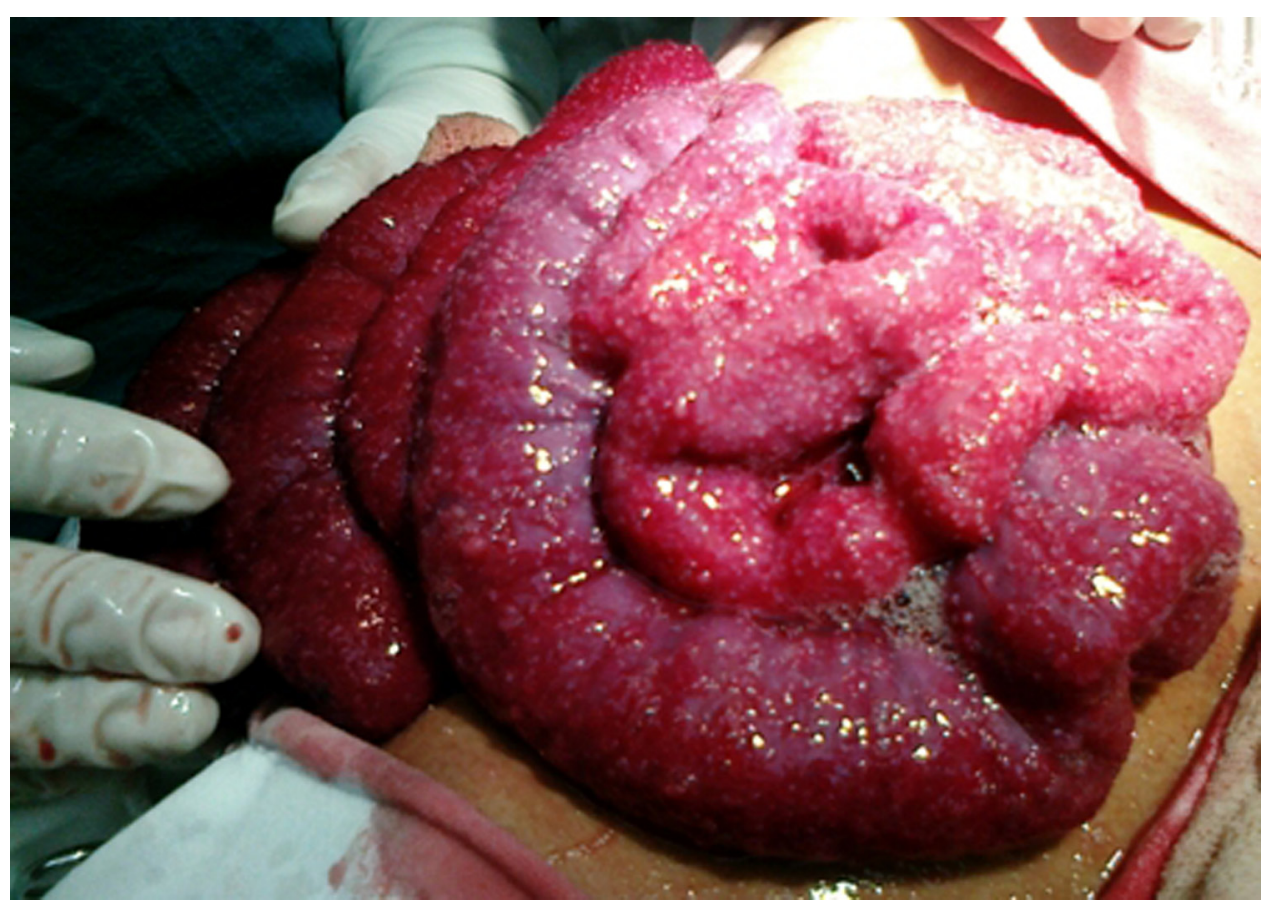

Figure 1 Intraoperative photograph depicting multiple granular deposits over the gut loops. 


\section{BMJ Case Reports}

Competing interests None.

Patient consent Obtained.

\section{REFERENCES}

1. Riquelme A, Calvo M, Salech F, et al. Value of adenosine deaminase (ADA) in ascitic fluid for the diagnosis of tuberculous peritonitis: a meta-analysis. J Clin Gastroenterol 2006:40:705-10.
2. Stanbury RM, Graham EM. Systemic corticosteroid therapy-side effects and their management. Br J Ophthalmol 1998:82:704-8.

3. Watorek E, Boratynska M, Smolska D, et al. Malignancy after renal transplantation in the new era of immunosuppression. Ann Transplant 2011;16:14-8.

This pdf has been created automatically from the final edited text and images.

Copyright 2012 BMJ Publishing Group. All rights reserved. For permission to reuse any of this content visit http://group.bmj.com/group/rights-licensing/permissions.

BMJ Case Report Fellows may re-use this article for personal use and teaching without any further permission.

Please cite this article as follows (you will need to access the article online to obtain the date of publication).

Negi BS, Thakur P, Negi MK, Revannasiddaiah S. Coincident intra-abdominal presentation of lymphoma and tuberculosis after long-term iatrogenic immunosuppression. BMJ Case Reports 2012;10.1136/bcr.12.2011.5395, Published XXX

Become a Fellow of BMJ Case Reports today and you can:

- Submit as many cases as you like

- Enjoy fast sympathetic peer review and rapid publication of accepted articles

- Access all the published articles

- Re-use any of the published material for personal use and teaching without further permission

For information on Institutional Fellowships contact consortiasales@bmjgroup.com

Visit casereports.bmj.com for more articles like this and to become a Fellow

Keep up to date with all published cases by signing up for an alert (all we need is your email address) http://casereports.bmj.com/cgi/alerts/etoc 